\title{
Efektywność działania wybranych banków spółdzielczych (na przykładzie województwa mazowieckiego)
}

\section{Wstęp}

Banki spółdzielcze w Polsce istnieją od ponad stu pięćdziesięciu lat i stanowią przeważająca grupę w sektorze bankowym. Obecnie jest ich 569 (stan na koniec kwartału 2014 r.). Każdy bank przez efektywne działanie dąży do maksymalizacji zysku. Banki spółdzielcze w porównaniu do banków komercyjnych mają do spełnienia również misję społeczną. Teoretycznie zysk w bankach spółdzielczych powinien być tylko narzędziem do realizacji celów, jakie wyznaczyli ich członkowie. Należy jednak podkreślić, że dobre wyniki finansowe są konieczne do przetrwania banku na rynku w świetle rosnącej konkurencji. Głównym czynnikiem efektywności działania banków spółdzielczych są udzielone kredyty dla przedsiębiorstw, przedsiębiorców indywidualnych, rolników i osób fizycznych. Banki spółdzielcze nadal odgrywają dużą rolę w polityce rolnej. Ich działanie $\mathrm{w}$ środowisku wiejskim i w małych miastach jest potrzebne do lokalnego rozwoju. Kredyty inwestycyjne dla rolników, objęte dopłatami do oprocentowania, są udzielane $\mathrm{w}$ większości przez banki zrzeszające BPS S.A. i SGB - Bank S.A. oraz banki spółdzielcze. Efektywność działania banków jest ważnym problemem badawczym decydującym o ich pozycji konkurencyjnej na rynku. Ocena efektywności jest więc istotnym problemem finansów i bankowości. Ujemna efektywność organizacji wiąże się ze stratami, a w konsekwencji prowadzi do ich upadłości. Ważność efektywności jako determinanty pozycji konkurencyjnej banków na rynku finansowym stała się motywem do podjęcia tej problematyki w niniejszej pracy. 


\section{Cele, hipotezy i metody badań}

Przed przystąpieniem do badań wyznaczono jeden cel badawczy, polegający na określeniu poziomu i determinant efektywności wybranych banków spółdzielczych prowadzących działalność na terenie województwa mazowieckiego.

Po określeniu celu badań sformułowano dwie hipotezy badawcze:

1. Wraz ze wzrostem wartości aktywów ogółem i kapitałów własnych banków spółdzielczych poziom efektywności ROA i ROE wzrasta.

2. Rodzaj zrzeszenia banków spółdzielczych ma statystycznie istotny wpływ na efektywność ich działania.

Do przeanalizowania efektywności banków wybrano kilka metod badawczych. Analizę wskaźnikową wykorzystano do określenia poziomu efektywności, a analizę korelacji do zbadania zależności między wskaźnikami efektywności ROA i ROE a wybranymi czynnikami makroekonomicznymi. Do zbudowania modeli ekonometrycznych efektywności BS-ów użyto analizy regresji krokowej wstecz. W pracy wykorzystano również metody tabelaryczną i graficzną prezentujące wyniki badań oraz studium literatury przedmiotu przedstawiające badania na świecie z tego zakresu.

Badaniami objęto 30 banków spółdzielczych z województwa mazowieckiego, spośród których 19 zrzeszonych było w BPS S.A., a 11 w SGB-Bank S.A. Z gmin miejskich pochodziło 14 banków, z gmin miejsko-wiejskich - 12, a z gmin wiejskich tylko 4 banki spółdzielcze. Zakres badań obejmował lata 2009-2012. Dobór banków do badań był losowy prosty, polegający na bezpośrednim i nieograniczonym ich doborze do próby statystycznej wprost z populacji generalnej i bez ograniczeń. Podstawą obliczeń były dane pochodzące ze sprawozdań finansowych publikowanych w Monitorze Spółdzielczym B. W badaniach efektywności analizowano wskaźniki efektywności ROA i ROE. Badając efektywność ze względu na wielkość aktywów ogółem, wyznaczono 3 grupy banków o sumie aktywów ogólem: poniżej $100 \mathrm{mln}$ zł, od 100 do $150 \mathrm{mln}$ zł i powyżej $150 \mathrm{mln}$ zł. Liczebność badanych BS-ów w poszczególnych grupach przedstawiono w tabeli 1 .

Tabela 1

Liczba badanych banków spółdzielczych ze względu na wielkość ich aktywów ogółem

\begin{tabular}{|l|c|c|c|c|}
\hline Aktywa ogółem & 2009 & 2010 & 2011 & 2012 \\
\hline Poniżej $100 \mathrm{mln}$ zł & 11 & 9 & 7 & 5 \\
\hline $100-150 \mathrm{mln}$ zł & 9 & 8 & 7 & 10 \\
\hline Powyżej $150 \mathrm{mln}$ zł & 10 & 13 & 16 & 15 \\
\hline Ogółem & 30 & 30 & 30 & 30 \\
\hline
\end{tabular}

Żródło: Badania własne. 
W przypadku badania efektywności ze względu na wielkości kapitałów własnych również podzielono banki na trzy grupy: poniżej $12 \mathrm{mln}$ zł, od 12 do $20 \mathrm{mln}$ zł i powyżej $20 \mathrm{mln}$ zł. Ich liczebność w poszczególnych grupach przedstawiono $\mathrm{w}$ tabeli 2 .

\section{Tabela 2}

Liczba badanych banków spółdzielczych ze względu na wielkość ich kapitałów własnych

\begin{tabular}{|l|c|c|c|c|}
\hline Kapitały własne & 2009 & 2010 & 2011 & 2012 \\
\hline Poniżej 12 mln zł & 16 & 12 & 11 & 9 \\
\hline 12-20 mln zł & 8 & 10 & 10 & 10 \\
\hline Powyżej 20 mln zł & 6 & 8 & 9 & 11 \\
\hline Ogółem & 30 & 30 & 30 & 30 \\
\hline
\end{tabular}

Źródło: Badania własne.

W celu określenia determinant efektywności ROA i ROE banków spółdzielczych województwa mazowieckiego zastosowano analizę regresji krokowej wstecz. Wykorzystano 34 wskaźniki finansowe z grup: wypłacalności i adekwatności kapitałowej, płynności finansowej, jakości aktywów i operacyjnych aktywów.

\section{Efektywność działania banków w świetle badań empirycznych na świecie}

Istnieje na świecie wiele badań dotyczących efektywności działania banków. $Z$ literatury przedmiotu wynika, że efektywność banków najczęściej jest badana wraz z innymi obszarami ich działalności. Wiele badań z zakresu efektywności dotyczy analizy porównawczej między różnymi grupami banków. Przykładowe badania $\mathrm{z}$ tego zakresu podano $\mathrm{w}$ tabeli 3 .

W prezentowanym przeglądzie badań użyto czterech metod: SFA - Stochastic Frontier Analysis (stochastyczna analiza graficzna), DEA - Data Enveloplment Analysis (analiza obwiedni danych), DFA - Distribution Free Approach (beztrendowa analiza fluktuacyjna) i analizę wskaźnikową. Wybrane badania obejmowały lata 1993-2014. Wynika z nich, że nie można jednoznacznie stwierdzić, że banki spółdzielcze odznaczały się lepszą lub gorszą efektywnością niż banki komercyjne. Wyniki badań są zróżnicowane w zależności od kraju, roku oraz wybranej metody badań. 
Tabela 3

Efektywność działania banków spółdzielczych - wyniki badań empirycznych na świecie

\begin{tabular}{|c|c|c|c|}
\hline Autorzy badań & Kraj & Metody badań & Wyniki badań \\
\hline $\begin{array}{l}\text { Altunbas i wsp. } \\
\text { [2001] }\end{array}$ & Niemcy & $\begin{array}{l}\text { SFA } \\
\text { DFA }\end{array}$ & $\begin{array}{l}\text { Banki spółdzielcze charakteryzowały się wyższą } \\
\text { efektywnością niż banki komercyjne. }\end{array}$ \\
\hline $\begin{array}{l}\text { Altunbas, } \\
\text { Evans, Molyneux } \\
\text { [2001] }\end{array}$ & Niemcy & SFA & $\begin{array}{l}\text { Banki spółdzielcze odznaczały się niższą efek- } \\
\text { tywnością kosztową i przychodową niż banki ko- } \\
\text { mercyjne. }\end{array}$ \\
\hline $\begin{array}{l}\text { Cebenoyan } \\
\text { i wsp. [1993] }\end{array}$ & USA & SFA & $\begin{array}{l}\text { Badania nie wykazały istotnych różnic w efektyw- } \\
\text { ności między bankami spółdzielczymi a komercyj- } \\
\text { nymi. }\end{array}$ \\
\hline $\begin{array}{l}\text { Hesse i Čihák } \\
\text { [2007] }\end{array}$ & Kraje UE & $\begin{array}{c}\text { Analiza } \\
\text { wskaźnikowa }\end{array}$ & $\begin{array}{l}\text { W latach 1994-2004 odnotowano w bankach spół- } \\
\text { dzielczych } 12 \text { krajów UE niższy poziom efektyw- } \\
\text { ności ROA i ROE niż w bankach komercyjnych. }\end{array}$ \\
\hline $\begin{array}{l}\text { Izquierdo i Na- } \\
\text { varro [2002] }\end{array}$ & Hiszpania & $\begin{array}{c}\text { Analiza } \\
\text { wskaźnikowa }\end{array}$ & $\begin{array}{l}\text { W latach 1991-1997 banki spółdzielcze wyka- } \\
\text { zywały niższy poziom efektywności niż banki ko- } \\
\text { mercyjne. }\end{array}$ \\
\hline Lang [1996] & Niemcy & SFA & $\begin{array}{l}\text { Stwierdzono niższą efektywność banków komer- } \\
\text { cyjnych niż banków spółdzielczych. }\end{array}$ \\
\hline Perek [2014] & Polska & DEA & $\begin{array}{l}\text { W latach 2005-2011 zróżnicowanie banków spół- } \\
\text { dzielczych pod względem efektywności technicz- } \\
\text { nej było wysokie. Najwyższy średni poziom efek- } \\
\text { tywności zaobserwowano w } 2009 \text { roku. }\end{array}$ \\
\hline $\begin{array}{l}\text { Rabobank } \\
\text { Annual Report } \\
\text { [2008] }\end{array}$ & $\begin{array}{l}\text { Austria } \\
\text { Francja } \\
\text { Holandia } \\
\text { Niemcy }\end{array}$ & $\begin{array}{c}\text { Analiza } \\
\text { wskaźnikowa }\end{array}$ & $\begin{array}{l}\text { W latach } 2002-2007 \text { stwierdzono niższa efektyw- } \\
\text { ność ROA i ROE w bankach spółdzielczych niż } \\
\text { w bankach komercyjnych, a pod względem pozio- } \\
\text { mu kosztów było odwrotnie. }\end{array}$ \\
\hline Siudek [2006] & Polska & $\begin{array}{c}\text { Analiza } \\
\text { wskaźnikowa }\end{array}$ & $\begin{array}{l}\text { W bankach spółdzielczych najsilniejszy wpływ na } \\
\text { wskaźnik ROE miała wielkość funduszy własnych } \\
\text { (1999 i 2001) oraz wielkość aktywów ogółem } \\
\text { (1996-1997 i 2001 r.). Na wskaźnik rentowności } \\
\text { ROA największy wpływ miały: wartość aktywów } \\
\text { ogółem, liczba zatrudnionych, liczba placówek } \\
\text { bankowych, liczba rachunków bankowych i licz- } \\
\text { ba gmin (2000-2002). Badania przeprowadzono } \\
\text { w latach 1995-2002. Próba badawcza liczyła } \\
1551 \text { banków. }\end{array}$ \\
\hline Siudek [2011] & Polska & DEA & $\begin{array}{l}\text { Banki komercyjne odznaczały się wyższa efek- } \\
\text { tywnościa techniczna niż banki spółdzielcze } \\
\text { w modelach o zmiennych efektach skali, zoriento- } \\
\text { wanych na efekty i nakłady. }\end{array}$ \\
\hline Weill [2002] & Kraje UE & DEA & $\begin{array}{l}\text { Banki spółdzielcze odnotowały wyższá efektyw- } \\
\text { ność niż spółdzielcze kasy oszczędnościowo-kre- } \\
\text { dytowe. }\end{array}$ \\
\hline Weill [2004] & Kraje UE & $\begin{array}{l}\text { DFA } \\
\text { SFA } \\
\text { DEA }\end{array}$ & $\begin{array}{l}\text { W jednych krajach europejskich efektywność ban- } \\
\text { ków spółdzielczych była wyższa niż w bankach } \\
\text { komercyjnych, w innych było odwrotnie. }\end{array}$ \\
\hline
\end{tabular}

Źródło: Opracowanie własne na podstawie studiów literatury przedmiotu. 


\section{Efektywność wybranych banków spółdzielczych na terenie województwa mazowieckiego}

Mówiąc o efektywności, należy rozpocząć od wskaźnika efektywności aktywów ogółem ROA. W badanych bankach z województwa mazowieckiego poziom ROA był wyższy w latach 2009-2010 i niższy w latach 2011-2012 w porównaniu do sektora bankowego, sektora banków komercyjnych i sektora banków spółdzielczych (tab. 4).

\section{Tabela 4}

Wskaźnik efektywności aktywów ogółem ROA banków w Polsce w latach 2009-2012 [\%]

\begin{tabular}{|l|c|c|c|c|}
\hline Wyszczególnienie & 2009 & 2010 & 2011 & 2012 \\
\hline Sektor bankowy & 0,81 & 1,03 & 1,26 & 1,22 \\
\hline Sektor banków komercyjnych & 0,83 & 1,1 & 1,27 & 1,23 \\
\hline Sektor banków spółdzielczych & 1,18 & 1,12 & 1,21 & 1,19 \\
\hline Badane banki spółdzielcze z województwa mazowieckiego & 1,21 & 1,18 & 1,2 & 1,19 \\
\hline
\end{tabular}

Źródło: Opracowanie własne na podstawie raportów NBP o sytuacji banków w latach 2009-2012 oraz pojedynczych sprawozdań finansowych BS-ów z województwa mazowieckiego w latach 2009-2012.

\section{Tabela 5}

Wskaźnik efektywności kapitałów własnych ROE banków w Polsce w latach 2009-2012 [\%]

\begin{tabular}{|l|c|c|c|c|}
\hline Wyszczególnienie & 2009 & 2010 & 2011 & 2012 \\
\hline Sektor bankowy & 8,37 & 10,21 & 12,64 & 11,19 \\
\hline Sektor banków komercyjnych & 8,22 & 10,19 & 12,71 & 11,19 \\
\hline Sektor banków spółdzielczych & 10,54 & 10,46 & 11,59 & 11,23 \\
\hline Badane banki spółdzielcze z województwa mazowieckiego & 14,10 & 12,52 & 12,85 & 12,56 \\
\hline
\end{tabular}

Źródło: Opracowanie własne na podstawie raportów NBP o sytuacji banków w latach 2009-2012 oraz pojedynczych sprawozdań finansowych BS-ów z województwa mazowieckiego w latach 2009-2012.

Kolejnym ważnym wskaźnikiem jest efektywność kapitałów własnych ROE. $\mathrm{Z}$ tabeli 5 wynika, że sektor banków spółdzielczych odnotował najniższe wahania tego wskaźnika, a badane banki z województwa mazowieckiego odznaczały się najwyższym jego poziomem spośród badanych grup.

Grupę trzydziestu badanych banków spółdzielczych z województwa mazowieckiego podzielono na trzy grupy pod względem wielkości aktywów ogółem, dla których obliczono wskaźniki efektywności ROA i ROE. Z rysunku 1 wynika, że najwyższą efektywność aktywów ogółem ROA wykazywały banki spółdziel- 


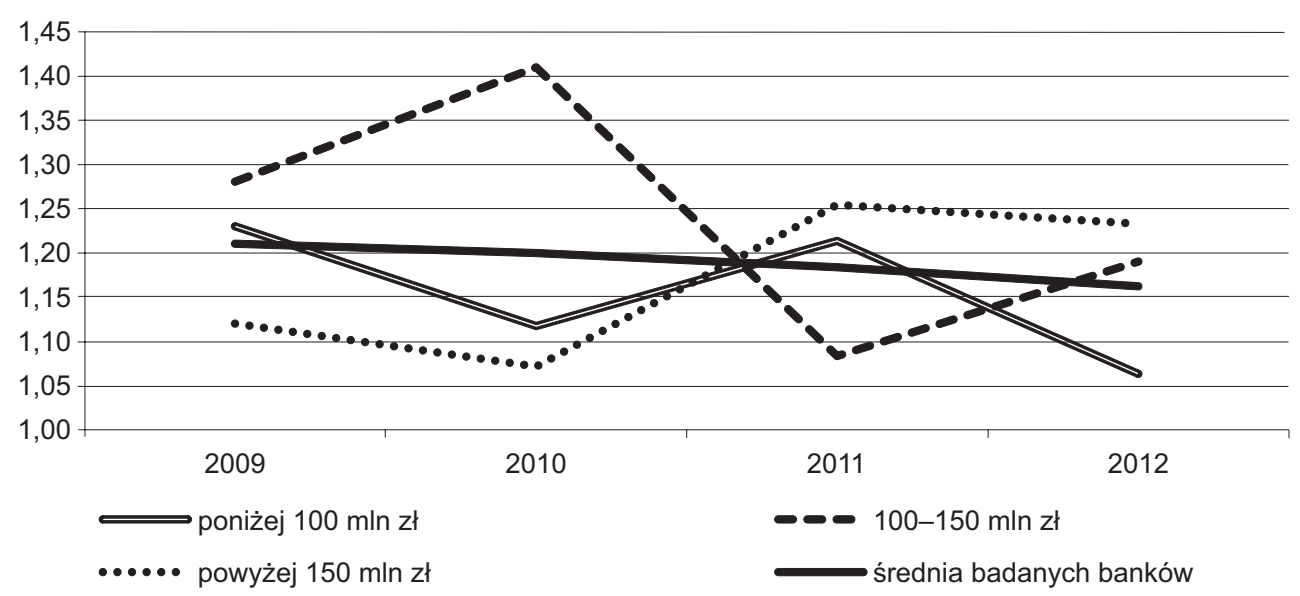

\section{Rysunek 1}

Wskaźnik efektywności ROA w wybranych bankach spółdzielczych województwa mazowieckiego ze względu na wielkość ich aktywów ogółem [\%]

Źródło: Badania własne.

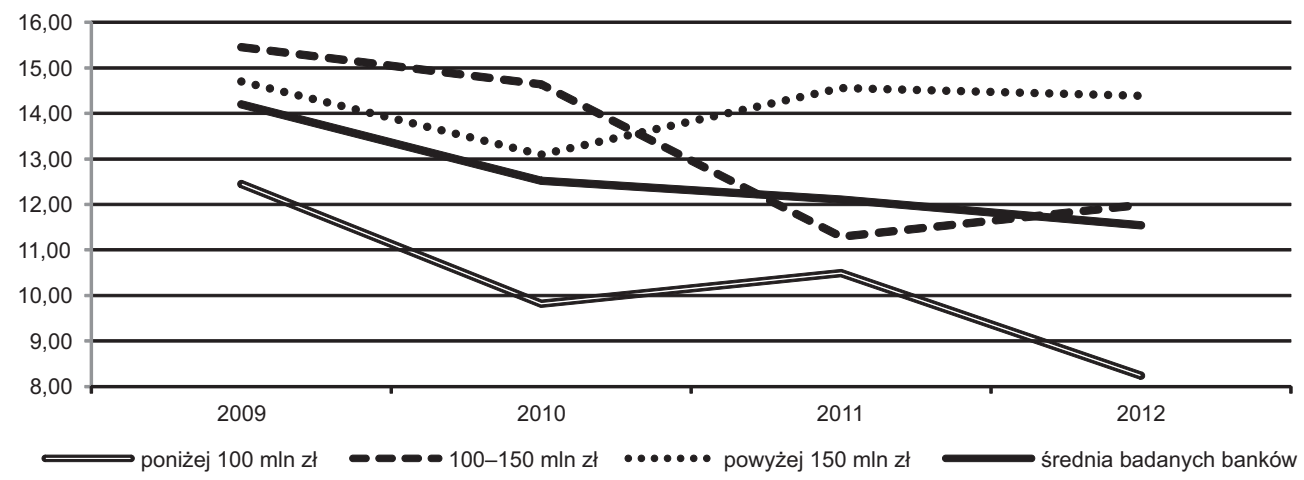

\section{Rysunek 2}

Wskaźnik efektywności ROE w wybranych bankach spółdzielczych województwa mazowieckiego ze względu na wielkość ich aktywów ogółem [\%]

Źródło: Badania własne.

cze w grupie 100-150 mln zł (lata 2009-2010) i w grupie powyżej $150 \mathrm{mln}$ zł (lata 2011-2012). Podobną sytuację zaobserwowano w przypadku wskaźnika efektywności ROE (rys 2).

Banki podzielono także na trzy grupy pod względem wielkości kapitałów własnych, dla których obliczono wskaźniki efektywności ROA i ROE. Z rysunku 3 wynika, że najwyższą efektywnością ROA odznaczały się BS-y w grupie 


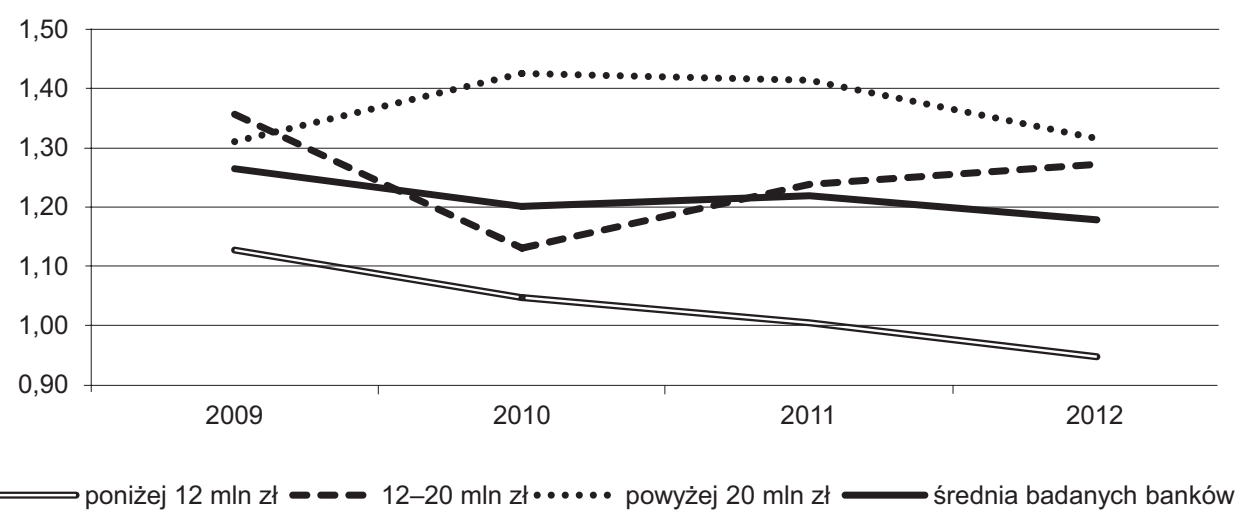

\section{Rysunek 3}

Wskaźnik efektywności ROA w wybranych bankach spółdzielczych województwa mazowieckiego ze względu na wielkość ich kapitałów własnych [\%]

Źródło: Badania własne.

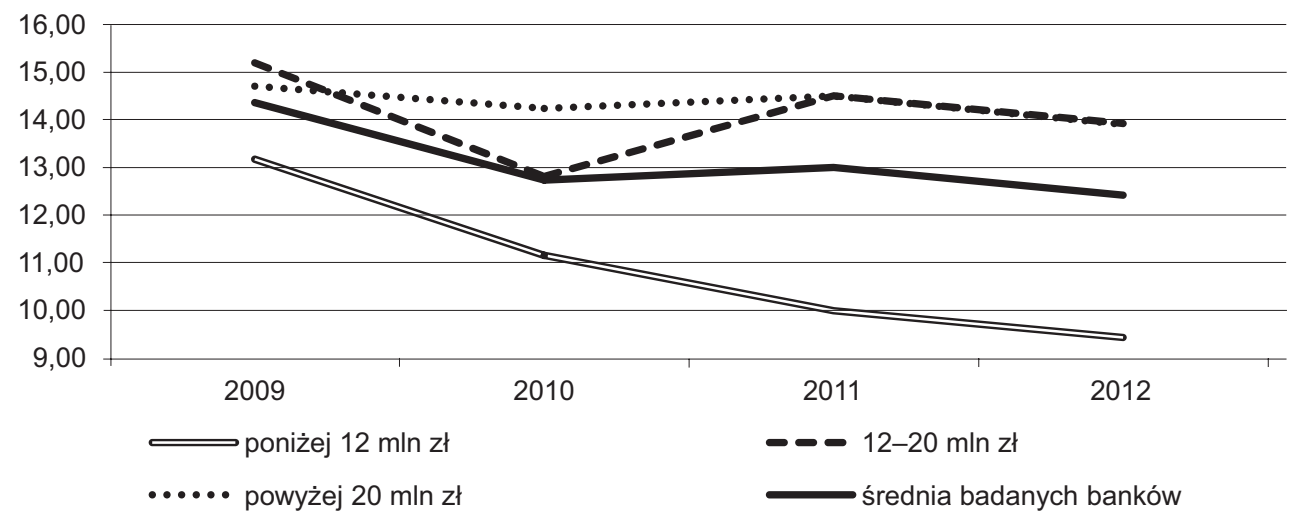

\section{Rysunek 4}

Wskaźnik efektywności ROE w wybranych bankach spółdzielczych województwa mazowieckiego ze względu na wielkość ich kapitałów własnych [\%]

Źródło: Badania własne.

o najwyższych kapitałach własnych, a najniższą w grupie o najniższych kapitałach własnych.

Przy analizie efektywności wskaźnika ROE (rys. 4) można zauważyć, że banki o najniższych kapitałach własnych charakteryzowały się najniższym wskaźnikiem ROE, a pozostałe dwie grupy odznaczały się ponadprzeciętnymi wartościami. 
Efektywność banków spółdzielczych analizowano również ze względu na ich przynależność do zrzeszenia (tab. 6). Z badań wynika, że banki spółdzielcze zrzeszone w SGB-Bank S.A. charakteryzowały się wyższym poziomem wskaźników efektywności ROA i ROE w latach 2010-2012 i niższym poziomem w 2009 roku niż w BPS S.A. Jednak należy podkreślić, że różnice między wynikami były niewielkie.

Wykorzystując analizę korelacji, zbadano wpływ wybranych czynników makroekonomicznych na poziom wskaźnika efektywności aktywów ogółem ROA i poziom wskaźnika kapitałów własnych ROE. Czynnikami makroekonomicznymi były: poziom inflacji, PKB per capita i wzrost PKB. Na podstawie analizy korelacji stwierdzono, że występuje silna, dodatnia korelacja między wskaźnikiem ROA a inflacją oraz silna, ujemna korelacja między wskaźnikiem ROE a PKB per capita. Wszystkie pozostałe korelacje były statystycznie nieistotne.

\section{Tabela 6}

Wskaźniki efektywności ROA i ROE wybranych banków spółdzielczych województwa mazowieckiego ze względu na rodzaj ich zrzeszenia [\%]

\begin{tabular}{|l|c|c|c|c|c|c|c|c|}
\hline \multirow{2}{*}{ Wyszczególnienie } & \multicolumn{2}{|c|}{2009} & \multicolumn{2}{c|}{2010} & \multicolumn{2}{c|}{2011} & \multicolumn{2}{c|}{2012} \\
\cline { 2 - 9 } & ROA & ROE & ROA & ROE & ROA & ROE & ROA & ROE \\
\hline Banki zrzeszone w SGB S.A. & 1,20 & 13,66 & 1,32 & 13,47 & 1,22 & 12,87 & 1,28 & 13,28 \\
\hline Banki zrzeszone w BPS S.A. & 1,21 & 14,36 & 1,09 & 11,98 & 1,19 & 12,83 & 1,14 & 12,15 \\
\hline
\end{tabular}

Źródło: Badania własne.

\section{Tabela 7}

Korelacje między wskaźnikami ROA i ROE a wybranymi czynnikami makroekonomicznymi

\begin{tabular}{|l|c|c|}
\hline Czynnik makroekonomiczny & ROA & ROE \\
\hline Inflacja & $0,76^{*}$ & 0,21 \\
\hline PKB per capita & $-0,08$ & $-0,64^{*}$ \\
\hline Wzrost PKB & $-0,27$ & $-0,44$ \\
\hline
\end{tabular}

*Współczynnik korelacji statystycznie istotny przy $p \leq 0,01$.

Źródło: Badania własne. 
W badaniach wyznaczono również determinanty wskaźników efektywności ROA i ROE. Z tabeli 8 wynika, że głównymi stymulantami efektywności ROA banków spółdzielczych województwa mazowieckiego były: wskaźnik udziału przychodów odsetkowych w aktywach ogółem, wskaźnik udziału funduszy podstawowych $\mathrm{w}$ aktywach ogółem i wskaźnik rozwiązanych rezerw w aktywach ogółem. Z kolei destymulantami efektywności ROA były: wskaźnik udziału kosztów działania w aktywach ogółem, wskaźnik udziału kosztów odsetkowych w aktywach ogółem i wskaźnik odpisów na rezerwy celowe w aktywach ogółem.

\section{Tabela 8}

Determinanty efektywności aktywów ogółem ROA w bankach spółdzielczych województwa mazowieckiego w latach 2009-2012

\begin{tabular}{|l|c|c|c|c|}
\hline \multicolumn{4}{|c|}{ Zmienna zależna [y]: wskaźnik efektywności aktywów ogółem ROA [\%] } \\
\hline \multirow{2}{*}{ Zmienne objaśniające } & \multicolumn{4}{c|}{ Współczynniki regresji } \\
\cline { 2 - 5 } & 2009 & 2010 & 2011 & 2012 \\
\hline Wartość stała & 1,14 & $-0,24$ & $0,93^{* *}$ & 0,27 \\
\hline $\begin{array}{l}\text { Wskaźnik udziału kosztów działania w aktywach } \\
\text { ogółem [\%] }\end{array}$ & $-0,53^{* *}$ & $0,09^{* *}$ & $-0,62^{* *}$ & $-0,58^{* *}$ \\
\hline $\begin{array}{l}\text { Wskaźnik udziału przychodów odsetkowych } \\
\text { w aktywach ogółem [\%] }\end{array}$ & $0,60^{* *}$ & - & $0,96^{* *}$ & $0,81^{* *}$ \\
\hline $\begin{array}{l}\text { Wskaźnik udziału kosztów odsetkowych w akty- } \\
\text { wach ogółem [\%] }\end{array}$ & $-0,70^{* *}$ & - & $-1,23^{* *}$ & $-0,89^{* *}$ \\
\hline $\begin{array}{l}\text { Wskaźnik udziału funduszy podstawowych } \\
\text { w aktywach ogółem [\%] }\end{array}$ & - & $0,02^{*}$ & - & - \\
\hline $\begin{array}{l}\text { Wskaźnik udziału wyniku odsetkowego w akty- } \\
\text { wach ogółem [\%] }\end{array}$ & - & $0,11^{* *}$ & $-0,18^{*}$ & - \\
\hline $\begin{array}{l}\text { Wskaźnik odpisów na rezerwy celowe w akty- } \\
\text { wach ogółem [\%] }\end{array}$ & - & - & $-0,92^{* *}$ & $-0,82^{* *}$ \\
\hline $\begin{array}{l}\text { Wskaźnik rozwiazzanych rezerw w aktywach } \\
\text { ogółem [\%] }\end{array}$ & - & - & $1,18^{* *}$ & $0,94^{* *}$ \\
\hline
\end{tabular}

* Statystycznie istotny współczynnik regresji dla zmiennych objaśniających przy $0,01 \leq p \leq 0,05$.

** Statystycznie istotny współczynnik regresji dla zmiennych objaśniających przy $p \leq 0,01$.

Źródło: Badania własne. 
Tabela 9

Determinanty efektywności kapitałów własnych ROE w bankach spółdzielczych województwa mazowieckiego w latach 2009-2012

\begin{tabular}{|l|c|c|c|c|}
\hline \multicolumn{5}{|c|}{ Zmienna zależna [y]: wskaźnik efektywności kapitałów własnych ROE [\%] } \\
\hline \multirow{2}{*}{ Zmienne objaśniające } & 2009 & 2010 & 2011 & 2012 \\
\hline Wartość stała & $28,18^{* *}$ & $-41,24$ & $19,50^{* *}$ & $15,49^{*}$ \\
\hline $\begin{array}{l}\text { Wskaźnik udziału funduszy podstawowych } \\
\text { w aktywach ogółem [\%] }\end{array}$ & $-1,11^{* *}$ & - & $-0,96^{* *}$ & $-0,71^{* *}$ \\
\hline $\begin{array}{l}\text { Wskaźnik udziału kosztów działania w akty- } \\
\text { wach ogółem [\%] }\end{array}$ & $-4,59^{* *}$ & $-4,84^{* *}$ & $-6,68^{* *}$ & $-4,84^{* *}$ \\
\hline $\begin{array}{l}\text { Wskaźnik udziału przychodów odsetkowych } \\
\text { w aktywach ogółem [\%] }\end{array}$ & $4,79^{* *}$ & - & $8,24^{* *}$ & $6,01^{* *}$ \\
\hline $\begin{array}{l}\text { Wskaźnik udziału kosztów odsetkowych w ak- } \\
\text { tywach ogółem [\%] }\end{array}$ & $-6,89^{* *}$ & - & $-10,70^{* *}$ & $-6,65^{* *}$ \\
\hline $\begin{array}{l}\text { Wskaźnik udziału wyniku odsetkowego w akty- } \\
\text { wach ogółem [\%] }\end{array}$ & - & $6,58^{* *}$ & - & - \\
\hline $\begin{array}{l}\text { Wskaźnik udziału depozytów w aktywach ogó- } \\
\text { łem [\%] }\end{array}$ & - & $0,52^{*}$ & - & - \\
\hline $\begin{array}{l}\text { Wskaźnik odpisów na rezerwy celowe w akty- } \\
\text { wach ogółem [\%] }\end{array}$ & - & - & $-10,06^{* *}$ & $-7,23^{* *}$ \\
\hline $\begin{array}{l}\text { Wskaźnik rozwiązanych rezerw w aktywach } \\
\text { ogółem [\%] }\end{array}$ & - & - & $12,93^{* *}$ & $7,82^{* *}$ \\
\hline
\end{tabular}

* Statystycznie istotny współczynnik regresji dla zmiennych objaśniających przy 0,01 $\leq p \leq 0,05$.

** Statystycznie istotny współczynnik regresji dla zmiennych objaśniających przy $p \leq 0,01$.

Źródło: Badania własne.

W przypadku determinant wskaźnika efektywności ROE (tab. 9) wystąpiły bardzo podobne zależności jak w przypadku wskaźnika efektywności ROA. Jedynie dodatkowymi determinantami były stymulanta wskaźnik udziału depozytów w aktywach ogółem i destymulanta wskaźnik udziału funduszy podstawowych w aktywach ogółem.

\section{Wnioski}

W ramach badań przeanalizowano efektywność wybranych banków spółdzielczych województwa mazowieckiego w latach 2009-2012. W wyniku przeprowadzonych badań wyciagnięto następujące wnioski:

1. Badane banki spółdzielcze w latach 2009-2010 miały wyższy wskaźnik efektywności aktywów ogółem ROA od banków całego sektora bankowego, 
sektora banków komercyjnych i sektora banków spółdzielczych. W dwóch kolejnych latach sytuacja była odwrotna.

2. W latach 2009-2012 badane banki spółdzielcze wykazywały wyższy wskaźnik efektywności kapitałów własnych ROE niż banki: w sektorze bankowym, w sektorze banków komercyjnych i w sektorze banków spółdzielczych.

3. Trudno jednoznacznie stwierdzić, która z grup badanych BS-ów województwa mazowieckiego była najlepsza i najgorsza pod względem wskaźników efektywności ROA i ROE. W badanych latach pod tym względem występowała duża zmienność, co powoduje, że hipotezę pierwszą odrzucamy.

4. Banki spółdzielcze zrzeszone w BPS S.A. wykazywały w 2009 roku efektywność ROA i ROE wyższą niż banki spółdzielcze zrzeszone w SGB-Bank S.A. W latach 2010-2012 sytuacja była odwrotna, co świadczy, że zrzeszenie nie miało wpływu na efektywność ROA i ROE w badanych BS-ach. Na tej podstawie możemy przyjąć, że druga hipoteza badawcza została odrzucona.

5. Na podstawie analizy korelacji stwierdzono, że poziom inflacji wpływał statystycznie istotnie dodatnio na poziom wskaźnika efektywności aktywów ogółem ROA, a PKB per capita statystycznie istotnie ujemnie na poziom wskaźnika efektywności ROE.

6. Głównymi stymulantami efektywności ROA i ROE badanych banków spółdzielczych województwa mazowieckiego były: wskaźnik udziału przychodów odsetkowych w aktywach ogółem, wskaźnik udziału funduszy podstawowych w aktywach ogółem i wskaźnik rozwiązanych rezerw w aktywach ogółem. Destymulantami efektywności ROA i ROE tych banków były: wskaźnik kosztów działania w aktywach ogółem, wskaźnik kosztów odsetkowych w aktywach ogółem i wskaźnik udziału odpisów na rezerwy celowe w aktywach ogółem.

\section{Literatura}

ALTUNBAS Y., EVANS L., MOLYNEUX P., 2001: Bank ownership and efficiency, Journal of Money, Credit \& Banking 33, 926-954.

CEBENOYAN A.S., COOPERMAN E.S., REGISTER C.A., 1993: Firm inefficiency and the regulatory closure of $S \& L s$ : An empirical investigation. Review of Economics and Statistics 75, 540-545.

DANIŁOWSKA A., 2009: Banki spółdzielcze a banki komercyjne w kredytowaniu rolników, Roczniki Naukowe Seria, t. XI, z. 5, s. 39-44.

HESSE H., ČIHAK M., 2007: Cooperative banks and financial stability, IMF Working Paper. WP/07/2. International Monetary Fund, 1-36.

IZQUIERDO R.S., Navarro A.M., 2001: Cooperative credit in Spain: An analysis of credit sections of cooperatives, Annals of Public \& Cooperative Economics 72(2), 229-252.

LANG G., 1996: Efficiency, profitability and competition, IFO Studien 4/1996, 537-561.

PEREK A., 2014: Wykorzystanie metody DEA do oceny efektywności banków spółdzielczych w Polsce, Economics and Management 3, 222-235. 
SIUDEK T., 2003: Rentowność działalności banków spółdzielczych w Polsce, Roczniki Naukowe SERiA t. V, z. 3, s. 125-130.

SIUDEK T., 2004: Koszty w bankach spótdzielczych w Polsce, [w:] Budżetowanie działalności jednostek gospodarczych. Teoria i praktyka, Wydawnictwo Krakowskie Towarzystwo Edukacyjne sp. z o.o., Kraków, s. 313-325.

SIUDEK T., 2006: Bankowość spółdzielcza w Polsce $w$ warunkach gospodarki rynkowej. Studium konkurencyjności, efektywności, organizacji, regulacji oraz perspektyw rozwoju, Wydawnictwo SGGW, Warszawa, s. 221-222.

SIUDEK T., 2006: Wybrane zagadnienia z finansów, Wydawnictwo SGGW, Warszawa, s. $12-16$.

SIUDEK T., 2008: Wplyw kredytów rolniczych udzielanych przez banki spóldzielcze na rozwój rolnictwa w Polsce, Zeszyty Naukowe SGGW, Ekonomika i Organizacja Gospodarki Żywnościowej 66, 37-47.

SIUDEK T., 2010: Polish cooperative banking sector in the face of systemic transformation and European integration in agriculture, Agricultural Economics 56(3), s. 116-134.

SIUDEK T., 2011: Bankowość spółdzielcza w Polsce $i$ w wybranych krajach Unii Europejskiej-wymiar ekonomiczny, organizacyjny i społeczny, Wydawnictwo SGGW, Warszawa, s. 188-190.

WEILL L., 2002: Does restructuring improve banking efficiency in a transition economy?, Applied Economics Letters vol. 9, 279-281.

WEILL L., 2004: Measuring cost efficiency in European banking: A comparison of frontier techniques, Journal of Productivity Analysis 21, 133-152.

\section{Abstrakt}

Celem pracy było określenie poziomu efektywności wybranych banków spółdzielczych z województwa mazowieckiego. Efektywność wyrażono wskaźnikami ROA i ROE. Badania przeprowadzono na 30 bankach spółdzielczych wybranych losowo. Z uzyskanych danych wynika, że wskaźnik ROA w badanych BS-ach w latach 2009-2010 był wyższy niż w sektorze banków komercyjnych i w sektorze banków spółdzielczych, a w latach 2011-2012 sytuacja była odwrotna. Z kolei wskaźnik ROE we wszystkich analizowanych latach w badanych bankach spółdzielczych był wyższy niż w sektorze banków komercyjnych i w sektorze banków spółdzielczych. Wielkość aktywów ogółem i kapitałów własnych banków spółdzielczych nie miała statystycznie istotnego wpływu na poziom ich efektywności ROA i ROE, co świadczy, że hipotezę pierwszą odrzucamy. Rodzaj zrzeszenia banków spółdzielczych nie wpływał statystycznie istotnie na poziom ich efektywności ROA i ROE, co oznacza, że hipotezę drugą odrzucamy.

Słowa kluczowe: banki spółdzielcze, efektywność, determinanty efektywności 


\title{
The efficiency of selected cooperative banks (for example of Masovian Voivodeship)
}

\begin{abstract}
The aim of this work was to determine the level of efficiency of selected cooperative banks from Masovian region. The efficiency was expressed by ROA and ROE indicators. The research was carried out in 30 randomly selected cooperative banks. The data show that the ROA ratio in surveyed cooperative banks in 2009-2010 was higher than in the commercial banking sector and cooperative banking sector, and in the years 2011-2012 the situation was the opposite. At the same time, ROE ratio for all analyzed years in surveyed cooperative banks was higher than in the commercial banking sector and cooperative banking sector. The size of total assets and equity of cooperative banks had no statistically significant effect on the level of their efficiency ROA and ROE, which means that we reject the first hypothesis. Type of association of cooperative banks did not influence statistically significantly on the level of their efficiency ROA and ROE, which means that we reject the second hypothesis.
\end{abstract}

Key words: cooperative banks, efficiency, efficiency determinants 
